\title{
Teleworking: decreasing mobility or increasing tolerance of commuting distances?
}

Emmanuel Ravalet

Patrick Rérat

Institute of geography and sustainability

University of Lausanne

To be published in: Built Environment, 45 (3) pp. 583-603

\section{Key-words}

Commuting, Teleworking, Homeworking, Mobility, Rebound Effect.

\begin{abstract}
Teleworking is widely considered to be a way of solving mobility issues by decreasing the number of commuting trips. However, little is known about teleworking and, more specifically, its links with spatial mobilities and the potential rebound effects. Statistical analysis of data from the Swiss Mobility and Transport Microcensus shows some limits to the ability of teleworking to regulate mobility in Switzerland. Firstly, commuting to a conventional workplace is replaced by (albeit shorter) journeys for other purposes. Secondly, and more importantly, teleworkers live further away from the workplace than their colleagues $(24.6 \mathrm{~km}$ vs. $16.1 \mathrm{~km})$. Our analysis shows that, although teleworking may reduce the number of commuting trips, it is likely to increase the distance travelled over a working week. Being able to work at home for part of the week may consequently decrease the propensity for residential relocation and increase tolerance for long distance commuting.
\end{abstract}




\section{Introduction}

Mobility is one of the main challenges faced by urban areas globally. Increased traffic notably results in congestion of infrastructure, air pollutants and greenhouse gas emissions. Addressing this issue is not an easy task and requires a rethink of both the supply and demand of transport. Teleworking represents a way of reducing mobility and, specifically, avoiding commuting. It is viewed as a tool to limit the environmental impacts of mobility and to reduce infrastructure congestion (Ravalet and Rérat, 2017). In Switzerland (the case study on which this paper is based), teleworking is widely accepted. It transcends political parties as it neither places costs on the community nor involves new taxes, it does not divide supporters of motorised mobility, public transport and active mobility, and it is seen as an additional choice for employees and a way for them to improve their work-life balance. Enthusiasm for teleworking is far from new, as shown by some seminal works. In his model on mobility transition, Zelinksy forecast that certain residential moves and circulatory movements "would be cancelled out by better communications, as travel is rendered redundant by more efficient transmission of messages for business, social, and educational purposes" (Zelinsky, 1971: 236). De Rosnay believed that teleworking would lead to the end of spatial concentration in urban areas and transport infrastructures and to a repopulation of rural and peripheral spaces (Rosnay, 1979).

Telecommuting is on the rise (Zhu and Mason, 2014; Kim et al., 2015; Swiss Confederation, 2016; e Silva and Melo, 2018), due notably to the development of innovations in information and communication technologies and to the transition to a postindustrial economy with the expansion of knowledge-based activities. The rise of third places such as co-working spaces is also a part of this development. Some critics of teleworking have focused on its infeasibility in sectors which require the co-presence of production factors or work with customers, and on its desirability both from the standpoint of employers (critics highlight, for example, issues of trust and control) and employees (e.g. sociability) (Aguilera et al., 2016).

Teleworking is likely to bring dramatic changes to the nature of employment and commuting. At first glance, it is a simple way of avoiding commuting - especially during rush hour - and of replacing movements across space with virtual interactions. But can we really be satisfied with this? Are there space-time rebound effects? In economics, a rebound effect is an increase in consumption that partially or totally offsets the gains made by using a new technology. Significant rebound effects have been identified in the fields of transport and mobility. In their seminal work, that is still a source of debate, Zahavi and Talvitie (1980) found that travel time budgets had been stable for some decades, despite the important speed gains represented by new modes and infrastructures of transport. This means that the gain in time (thanks to the increase in speed) is generally reinvested in additional distances. As suggested by Rietveld (2011), could this reasoning be applied to teleworking?

This paper presents an exploratory analysis of the impacts of teleworking on mobility practices (e.g. distances travelled, use of the car), using Switzerland as a case study. After a literature review on teleworking, its various forms and its links with spatial mobilities, we present the data base used in this paper. The empirical section is divided into two stages, looking first at the prevalence of teleworking in the case of Switzerland and its popularity according to employment context and socio-demographic profile, and second at links between telecommuting and mobility practices. Teleworkers are compared to non-teleworkers with regard to the distance of their commute, the distances they travel for all reasons on working days and over the week, and the transportation mode used. The distances travelled on teleworking and non-teleworking days are also compared. On the whole, the paper shows 
that teleworking is more frequent among employees who have longer distances to travel between their home and place of work. However, while teleworking reduces the number of commuting trips, it may increase the distance travelled over a working week.

\section{Theoretical elements}

\subsection{The various forms of teleworking}

It is crucial to start the discussion on teleworking by stating its definition, as it covers a wide variety of situations (Thomsin, 2002; Sullivan, 2003). This diversity is often only partially taken into account in official surveys on mobility or the labour market, affecting in turn researchers' analysis of teleworking.

In 1991, Mokhtarian defined teleworking as "using telecommunications technology at home, or at a location close to home, during regular work hours, instead of commuting to a conventional workplace" (Mokhtarian, 1991, 275). The words "instead of" imply a replacement of the workplace: teleworking entails working somewhere other than the usual place of work (Melo and e Silva, 2017). The use of ICT is also a significant aspect of teleworking. These criteria exclude those people who normally work at home (e.g. self-employed workers) or whose activity is decentralised, as this does not represent an alternative to commuting. The term 'teleworker' is often limited to people who are employed (rather than self-employed) and who have a conventional workplace outside the home (Aguiléra et al., 2016). Sullivan (2003) discussed the need to define a weekly percentage of teleworking time, which led Parent-Thirion et al. (2007) estimate that $20 \%$ of European employees spend at least a quarter of their working time at home, compared to less than $3 \%$ who spend all or most of their time at home. In 2015 , in Switzerland, the proportion of regular teleworkers (teleworking for more than $50 \%$ of their working hours) is estimated at $1.3 \%$, while that of occasional teleworkers (less than $50 \%$ of their working time) is estimated at $19.7 \%$ (Swiss Confederation, 2016).

It is important to consider the nature of the work activities performed outside the workplace (Maruyama and Tietze, 2012). In a recent report on legal issues on the subject, a distinction is made between partial and total teleworking depending on whether an employee performs his/her work tasks outside the office for part of the day (e.g. answering emails before commuting) or the whole day (Swiss Confederation, 2016).

Earlier definitions of teleworking referred to working at or close to home in order to avoid or reduce commuting trips. This is unnecessarily limiting, since telework can be done in various places, sometimes far from the main home. Three main forms of teleworking can be identified (Thomsin, 2002): (1) Teleworking at home for all or part of a day (e.g. to avoid rush hour), (2) Itinerant telework (e.g on a train), (3) Teleworking in third places, which may be dedicated (e.g. co-working spaces) or not (cafés, etc.).

\subsection{Characteristics of teleworkers}

Although teleworking is on the rise, it does not affect all workers to the same extent. There are of course sectors in which teleworking is developing much more significantly (Walrave and De Bee, 2005; Vilhelmson and Thulin, 2016), namely service companies, financial institutions, and institutions operating in the information and communication sectors, but productive activities (agriculture, industry) and personal services are less affected.

The differences between sectors may also be explained by the fact that teleworking is still largely informal: such practices are generally authorised by the employer but they are rarely the subject of a convention or document formalising the procedure (Thomsin, 2002; Taskin and Vendramin, 2004; Song, 2009). Although teleworking and 
flexible working hours are not necessarily linked, the development of informal telework does often seem to be associated with flexible working practices (Taskin and Schots, 2005; Ernst, 2007). Several other employment criteria also play a role in the propensity for teleworking. Among others, we can point to managerial trust and control, and type of job, work tasks and responsibilities (Vilhelmson and Thulin, 2016; Singh et al., 2013).

It is difficult to pinpoint individual characteristics and their potential impact on the propensity of employees to telework, particularly regarding the effects of gender, age and the presence of children in households (Singh et al., 2013, e Silva and Melo, 2018). In terms of socioeconomic status, it is consistently demonstrated that the people with the highest incomes and highest levels of education are most likely to telework (e Silva and Melo, 2018).

\subsection{The links between teleworking and the various forms of spatial mobility}

In this paper, we consider the links between teleworking and the spatial mobility of the people concerned. A primary effect of teleworking is to limit the number of commuting trips. However, in the early 1990s, another hypothesis was made regarding a possible rebound effect: longer commuting distances would become acceptable due to the possibility of teleworking at home or in a dedicated place near to home (Nilles, 1991; Janelle, 1986). This hypothesis has not been proven, since the only evidence observed is that teleworkers tend to live further away from their main place of work than others (Zhu, 2013; Helminen and Ristimaki, 2007; Ory and Mokhtarian, 2006; Mokhtarian et al., 2004; Peters et al., 2004; Rietveld 2011, Lachapelle et al. 2017).

The mechanism behind this trend has not yet been fully addressed. It may be the result of a negotiation with the employer (e.g. in order to take care of children, or for quality of life issues) that took place after the residential choice. However, no research has assessed the possibility of greater tolerance for commuting distance induced by the possibility of teleworking. Teleworking could, for example, be seen as an incentive (1) to choose a home that is remote from the workplace, (2) not to relocate, or (3) to accept or keep a job far away from home. As teleworking could play a role in the choice of places of residence and work, and also distances travelled, the question of the modes of transport used then arises, for both commuting trips and all other trips (Zhu and Mason, 2014, and e Silva and Melo, 2018).

A further element is that telework could generate trips that would not take place if people spent a usual day in the workplace. In South Korea, for example, Kim (2017) shows that non-work-related trips on teleworking days amount to 4 kilometres on average. Perch-Nielsen et al. (2014) estimate that 7 to $23 \%$ of the savings on travel due to teleworking are offset by compensation effects related to extra distances travelled for other purposes (e.g. leisure, childcare, shopping). In their literature review, Walls and Safirova (2004) report that vehicle miles travelled are $53 \%$ to $77 \%$ lower on telecommuting days than on non-telecommuting days in the United States. It therefore appears that teleworking makes it possible to use the time saved by not travelling to work for other trips. In this paper we aim to address the question of the extent to which teleworking reduces the distance travelled daily. Before we can do this, it is necessary to look into the incidence of teleworking and to better understand who teleworkers are. As the context is changing rapidly (digitalisation, economic restructuring, etc.), we will also look at recent evolutions in teleworking. 


\section{Methodology}

This paper addresses teleworking in Switzerland, which provides an interesting case study for several reasons. First, it is a tertiary economy in which many sectors are conducive to teleworking. There is extensive transport infrastructure - both road and rail - and both information and communication technologies are highly developed, including in the more peripheral regions. Moreover, Swiss people tend to be quite attached to their place of residence and are rather reluctant to move (and in particular to change their canton of residence) because of their employment (Ravalet et al., 2015, Rérat, 2014). In addition, the importance of internal migration is declining, while long-distance commuting is on the rise. Teleworking could play an increasing role in the trade-offs between private life and work life, and may strengthen this trend.

Beyond some pioneering works (see for example Rumley et al., 1999), few studies have addressed teleworking in Switzerland and the different forms of mobility avoided or generated by teleworking. Only one study, funded by the Swiss Federal Office of Energy (Perch-Nielsen et al., 2014), considers two effects: induced trips on teleworking days and energy consumption related to home heating. The longer distances between home and work for teleworkers are mentioned but not studied, and the subject is approached from the perspective of companies rather than employees, which limits telework to its formal dimension.

This paper is based on the Mobility and Transport Microcensus (MTMC), which is the major data set in the field of mobility in Switzerland. This telephone survey is conducted every five years by the Federal Statistical Office (OFS) and the Federal Office for Spatial Development (ARE). The two most recent editions (2010 and 2015) are used here to measure the evolution of the practice of teleworking. The survey is conducted throughout a full year in order to avoid possible seasonal variations in terms of activities and travel. It reports on the mobility practices of Swiss residents based on all journeys made by respondents on the day before the survey.

The sample sizes allow for relatively accurate statistical analysis: 62,868 households were interviewed in 2010 and 57,090 in 2015. In each of the households surveyed, a single person recorded all of the trips he or she had made the day before. A weighting coefficient, calculated by the Federal Statistical Office, is applied to the sample. In addition, 10,982 employees in 2010 (and 8,573 in 2015) answered a module on "active mobility and employment situation", which included a number of questions about teleworking at home.

The first step was to define teleworking on the basis of the theoretical discussion and the content of the survey. We used questions on home teleworking ("Do you telework at home?") and on the time dedicated to teleworking ("How much of your work time do you do at home?"). The available data does not take into account teleworking outside the home (in third places, other places dedicated to teleworking, or while travelling). We classified employees into those who telework at home for a large part of their working time (over 30\%), a small part (less than $30 \%$ ) or who never telework. The $30 \%$ threshold corresponds to one and a half days of teleworking per week for full-time workers. This threshold has emerged over the course of the analysis as a relevant limit in terms of professional situation and socio-demographic profile (see sections 3.2 and 3.3). Throughout this paper, we will refer to intensive telehomework for the former category and partial telehomework for the latter.

More than two-thirds of self-employed people work at home for part of their working time. This situation is often associated with a lack of a conventional workplace, flexibility in the organisation of their working time or the frequency of overtime. For the following analysis we restrict the definition of telework (as discussed above) to employees and do not consider self-employed people. 
The literature review highlights the influence of the sociodemographic profiles, working conditions and spatial locations on the propensity to telework. The factors that we have taken into account are underpinned by the literature and the availability of variables in databases. We decided to include age, gender, level of education, income and household type as sociodemographic issues, and working time flexibility, hours of work, hierarchical responsibility, potential link to ownership of the company and, finally, business sector in terms of assessment of working conditions. On the spatial issue, we considered the residential location of employees in core cities, suburban municipalities, isolated cities or rural areas.

The MTMC provides information on the respondents' mobility practices on the day before they were interviewed so we can infer some information on the effect of teleworking on other forms of mobility. Since we do not know what activity the respondents are engaged in when they are at home, we can only consider teleworkers who work full-time and who were surveyed on a weekday. This minimises the risk of confusion between teleworking days and days when the respondent did not work (holidays, sickness, etc.). Teleworking days are considered to be worked weekdays when the employee spends at least 6 hours at home between $9 \mathrm{am}$ and $5 \mathrm{pm}$. Working days in the office are considered as such when the respondent spends at least 6 hours at the workplace within the same time slot. For the samples to be sufficiently large, we included both partial and intensive teleworkers in this analysis. As part of this approach, we compared the commuting distances between teleworkers and non-teleworkers. In the MCMT, the distances are calculated on the basis of geolocated origins and destinations. The transport offer is then considered to correct distances as the crow flies. To test the robustness of the differences in commuting trips we also applied a linear regression using the independent variables mentioned above. We completed the analysis by addressing modes of transport, as well as all journeys made on a workday.

\section{Results}

\subsection{Frequency of teleworking in the labour force}

In 2015, a quarter of Swiss employees carried out telework at home (Figure 1). However, and echoing Sullivan (2003), the majority teleworked for only a small part of their working time: $18.2 \%$ of employees teleworked partially and $6.1 \%$ in an extensively way. These figures are approximately two percentage points higher than in $2010(16.5 \%$ and $4.6 \%)$. Such results are in line with those obtained by the Swiss Confederation (2016) but are slightly lower than those found by Deloitte (2016). Both studies detail the development of teleworking without linking it with mobility practices. In Deloitte (2016), the share of employees teleworking at home for at least one half-day per week is estimated at $28 \%$. 
Figure 1: Telehomeworking in Switzerland in 2010 and 2015

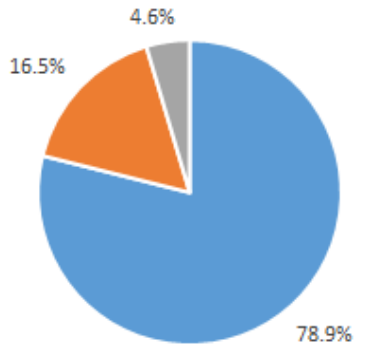

2010

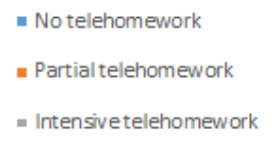

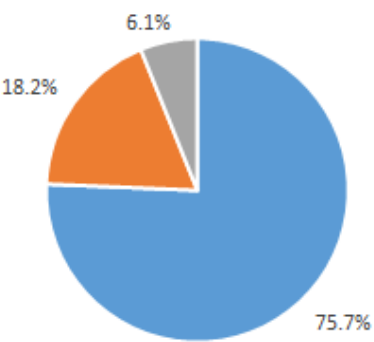

2015

Source: MTMC 2010, N=9261 and MTMC 2015, N=8700, OFS, ARE

Teleworking is distributed very differently among the labour force. We carried out a multiple regression analysis on the 2010 and 2015 data to analyse the role of various independent or explanatory variables (sociodemographic profile, working conditions and spatial context). In so doing, we summarised the information and determined the influence of each independent variable, all things being equal, on the dependent variables, which consist of partial teleworking, intensive teleworking and no teleworking. The influence of each independent variable was measured by way of an odds ratio - referred to as $\exp (\mathrm{B})$ - which represents the ratio of the odds of an event (e.g. teleworking) occurring in one group compared to another (a reference group). If the odds ratio is higher (or lower) than one, the odds of teleworking is more (or less) likely in the group under study than in the reference group.

This analysis of the 2010 database (table 1) does not show any effect for most sociodemographic variables on teleworking practices. Neither gender, age, nor households structure have a significant effect. Only income and education levels play a significant role: the higher the level of these variables, the more frequent the use of partial teleworking. Residential location does not have any impact on the propensity to telework.

Table 1: Logistic regression on telehomework practices in 2010

\begin{tabular}{|c|c|c|c|c|c|c|c|c|}
\hline & \multirow{2}{*}{2010} & \multirow{2}{*}{$\begin{array}{c}\text { No } \\
\text { telehomework } \\
\text { (ref.) }\end{array}$} & \multicolumn{3}{|c|}{ Partial telehomework } & \multicolumn{3}{|c|}{ Intensive telehomework } \\
\hline & & & B & S.E. & $\operatorname{Exp}(B)$ & B & S.E. & $\operatorname{Exp}(B)$ \\
\hline \multirow{2}{*}{ Age } & Less than 30 y.o. & & -0.211 & 0.314 & 0.809 & -0.562 & 0.517 & 0.570 \\
\hline & More than 30 y.o. (ref.) & & & & & & & \\
\hline \multirow{2}{*}{ Gender } & Woman (ref.) & & & & & & & \\
\hline & Man & & 0.196 & 0.286 & 1.217 & -0.462 & 0.527 & 0.630 \\
\hline \multirow{3}{*}{$\begin{array}{c}\text { Educational } \\
\text { level }\end{array}$} & Obligatory school only (ref.) & & & & & & & \\
\hline & Secondary school & & 0.744 & 0.535 & 2.105 & 0.267 & 0.695 & 1.306 \\
\hline & High school & & 1.250 & 0.553 & $3.491 * *$ & 0.462 & 0.739 & 1.588 \\
\hline \multirow{4}{*}{$\begin{array}{l}\text { Household } \\
\text { type }\end{array}$} & Alone & & -0.112 & 0.362 & 0.894 & -0.559 & 0.605 & 0.572 \\
\hline & Childless couple (ref.) & & & & & & & \\
\hline & Couple with child(-ren) & & -0.157 & 0.284 & 0.855 & -0.604 & 0.471 & 0.547 \\
\hline & Single parent family & & -0.472 & 0.575 & 0.624 & -2.863 & 1.847 & 0.057 \\
\hline \multirow{3}{*}{$\begin{array}{l}\text { Household } \\
\text { Income }\end{array}$} & Low incomes (ref.) & & & & & & & \\
\hline & Medium incomes & & -0.118 & 0.476 & 0.889 & -0.123 & 0.743 & 0.884 \\
\hline & High incomes & & 0.443 & 0.268 & $1.558^{*}$ & 0.614 & 0.469 & 1.849 \\
\hline
\end{tabular}




\begin{tabular}{|c|c|c|c|c|c|c|c|}
\hline \multirow{3}{*}{$\begin{array}{l}\text { Flexibility in } \\
\text { working time }\end{array}$} & $\begin{array}{l}\text { Fixed times at the beginning } \\
\text { and / or end of the day (ref.) }\end{array}$ & & & & & & \\
\hline & $\begin{array}{l}\text { Set work periods or number } \\
\text { of hours }\end{array}$ & 0.443 & 0.302 & 1.557 & -0.163 & 0.502 & 0.849 \\
\hline & Totally flexible schedules & 1.568 & 0.305 & $4.796^{* * *}$ & 1.169 & 0.478 & $3.219 * *$ \\
\hline \multirow{3}{*}{$\begin{array}{l}\text { Employment } \\
\text { rates }\end{array}$} & full time (ref.) & & & & & & \\
\hline & part-time & -0.235 & 0.299 & 0.791 & -0.316 & 0.491 & 0.729 \\
\hline & Several partial times & 0.967 & 0.666 & 2.631 & 2.459 & 0.907 & $11.690 * * *$ \\
\hline \multirow{2}{*}{$\begin{array}{l}\text { Hierarchical } \\
\text { responsabilities }\end{array}$} & $\begin{array}{l}\text { with no management } \\
\text { responsability (ref.) }\end{array}$ & & & & & & \\
\hline & $\begin{array}{l}\text { with line management } \\
\text { responsability }\end{array}$ & 0.653 & 0.274 & $1.921^{* *}$ & -0.140 & 0.545 & 0.870 \\
\hline \multirow{2}{*}{$\begin{array}{l}\text { Company } \\
\text { ownership }\end{array}$} & $\begin{array}{l}\text { Employee in a self-owned or a } \\
\text { family member business }\end{array}$ & 0.293 & 0.536 & 1.340 & 2.164 & 0.884 & $8.707^{* *}$ \\
\hline & $\begin{array}{l}\text { Employee in another company } \\
\text { (ref.) }\end{array}$ & & & & & & \\
\hline \multirow{10}{*}{ Business sectors } & Trade, mechanical repair & 0.217 & 0.571 & 1.243 & 0.456 & 1.258 & 1.578 \\
\hline & Transport, storage, post & -0.312 & 0.688 & 0.732 & -16.785 & 6149.836 & 0.000 \\
\hline & Accommodation and catering & -0.921 & 1.496 & 0.398 & -16.743 & 9751.254 & 0.000 \\
\hline & $\begin{array}{l}\text { Information and } \\
\text { communication }\end{array}$ & 1.576 & 0.536 & $4.835 * * *$ & 0.470 & 1.607 & 1.599 \\
\hline & Banks, insurance & 0.210 & 0.509 & 1.233 & -17.927 & 5960.160 & 0.000 \\
\hline & Public administration (ref.) & & & & & & \\
\hline & Education & 2.652 & 0.482 & $14.189 * * *$ & 3.530 & 1.021 & $34.120^{* * *}$ \\
\hline & Health, social, medico-social & 0.695 & 0.445 & 2.004 & 1.895 & 0.968 & $6.655^{* *}$ \\
\hline & Other, property repairs & 0.106 & 0.518 & 1.111 & 0.938 & 1.064 & 2.555 \\
\hline & Domestic services & 1.135 & 0.564 & $3.111^{* *}$ & 1.324 & 1.140 & 3.759 \\
\hline \multirow{5}{*}{$\begin{array}{l}\text { Residential } \\
\text { location }\end{array}$} & Core cities (ref.) & & & & & & \\
\hline & Suburban municipalities & -0.212 & 0.264 & 0.809 & -0.128 & 0.496 & 0.880 \\
\hline & Isolated cities & 1.222 & 0.943 & 3.393 & -17.103 & 1761.068 & 0.003 \\
\hline & Rural municipalities & -0.148 & 0.358 & 0.862 & 0.581 & 0.594 & 1.788 \\
\hline & Constant & -3.841 & 0.770 & $0.021^{* * *}$ & -4.193 & 1.293 & $0.015^{* * *}$ \\
\hline
\end{tabular}

${ }^{*} \mathrm{p}<0.05-{ }^{* *} \mathrm{p}<0.01-* * * \mathrm{p}<0.001$

Model characteristics: Likelihood log. 486.947 - Cox R2 0.204 - Nagelkerke R2 0.322 - $\mathrm{p}<0.001$

Source: MTMC 2015, N=9261, OFS, ARE

Flexibility of working hours greatly facilitates teleworking (both partial and intensive) since it may lead to informal teleworking situations, which are still dominant according to the literature. Conversely, a lack of flexibility may indicate a need for co-presence (with colleagues, customers, etc.). Working hours do not play a significant role in the use of teleworking, except for workers who have several part-time jobs and who telework more frequently in an intensive way.

People with hierarchical responsibilities have a much greater tendency towards partial telework, but not intensive telework. The question is whether this time spent working at home is part of their regular working hours (and therefore performed at home rather than at the conventional workplace), or whether it is overtime during evenings or weekends. It is difficult to answer this on the basis of the available data. This possible form of teleworking at home does not prevent commuting but rather allows people to "work more" without necessarily "being more 
present at the office". When an employee owns the company s/he works for, or when this company belongs to a family member, teleworking is significantly more common. This tendency is extremely evident in the case of intensive teleworking. The understanding is that such situations are probably similar to the case of self-employed workers.

The last element concerns activity sector. Partial telework is particularly common in three categories: information and communication, education, and domestic services. Overall, the tertiary sector, with the exception of personal services, is associated with a high rate of partial telework. Intensive telework is focused more specifically within teaching professions. In fact, these results raise the question of the very nature of professional activity performed at home. Can we really talk about telecommuting at home when a teacher finishes preparing for a school day at home in the evening? More generally, is reading or answering professional emails in the evening a form of teleworking? The great variety of professional activities that can be carried out outside the conventional workplace requires better identification in surveys in the future to better understand the use of teleworking.

Several differences are observed between the results obtained in 2015 (table 2) and those of 2010. Although the incidence of telework rose (both in partial and intensive form) from 2010 to 2015, the differences became more pronounced between distinct groups of workers. In 2015, people under 30 years of age telework less than those aged over 30. Their recent entry into working life, and limited hierarchical responsibilities, is probably an obstacle to the spread of teleworking. The under-representation of people with a high level of education in this age group (since they enter the labour market later) is another explanation. Men are more likely to partially telework at home than women (which may be explain by the fact that they usually commute over longer distances). In table 1 , we observed that age and gender played no role on teleworking in 2010. The results obtained for 2015 show that teleworking did not increase at the same rate for both men and women, or for all age categories. Family structure also played an important role in 2015, since single parent families are more likely to telework at home than couples without children. This highlights the opportunities offered by teleworking to improve life-work balance (Tremblay et al., 2006).

Table 2: Logistic regression on telehomework practices in 2015

\begin{tabular}{|c|c|c|c|c|c|c|c|c|}
\hline & \multirow{2}{*}{2015} & \multirow{2}{*}{$\begin{array}{c}\text { No } \\
\text { telehomework } \\
\text { (ref.) }\end{array}$} & \multicolumn{3}{|c|}{ Partial telehomework } & \multicolumn{3}{|c|}{ Intensive telehomework } \\
\hline & & & B & S.E. & $\operatorname{Exp}(B)$ & B & S.E. & $\operatorname{Exp}(B)$ \\
\hline \multirow{2}{*}{ Age } & Less than 30 y.o. & & -0.601 & 0.310 & $0.548^{*}$ & -2.595 & 0.787 & $0.075^{* * *}$ \\
\hline & More than 30 y.o. (ref.) & & & & & & & \\
\hline \multirow{2}{*}{ Gender } & Female (ref.) & & & & & & & \\
\hline & Male & & 0.882 & 0.269 & $2.416^{* * *}$ & -0.118 & 0.542 & 0.888 \\
\hline \multirow{3}{*}{$\begin{array}{l}\text { Educational } \\
\text { level }\end{array}$} & Obligatory school only (ref.) & & & & & & & \\
\hline & Secondary school & & 1.277 & 0.849 & 3.584 & 1.419 & 0.987 & 4.131 \\
\hline & High school & & 2.679 & 0.852 & $14.566 * * *$ & 2.576 & 1.041 & $13.150 * *$ \\
\hline \multirow{4}{*}{$\begin{array}{l}\text { Household } \\
\text { type }\end{array}$} & Alone & & 0.259 & 0.342 & 1.296 & -0.937 & 0.666 & 0.392 \\
\hline & Childless couple (ref.) & & & & & & & \\
\hline & Couple with child(-ren) & & -0.414 & 0.295 & 0.661 & -0.641 & 0.494 & 0.527 \\
\hline & Single parent family & & 1.316 & 0.467 & $3.729 * * *$ & 0.428 & 0.804 & 1.534 \\
\hline \multirow{2}{*}{$\begin{array}{l}\text { Household } \\
\text { Income }\end{array}$} & Low incomes (ref.) & & & & & & & \\
\hline & Medium incomes & & -1.175 & 0.488 & $0.309 * *$ & 0.270 & 0.732 & 1.309 \\
\hline
\end{tabular}




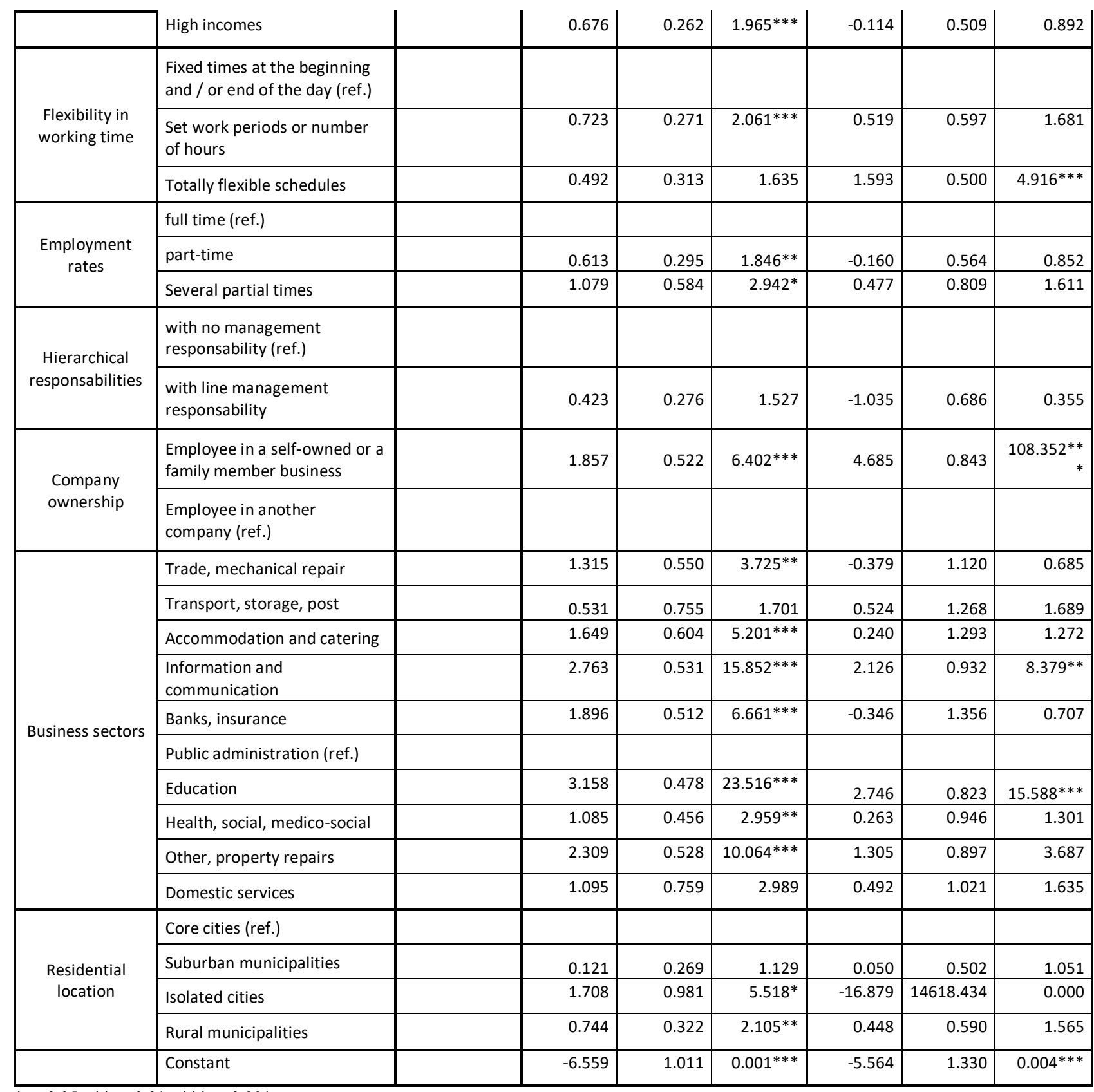

$* \mathrm{p}<0.05-* * \mathrm{p}<0.01-* * * \mathrm{p}<0.001$

Model characteristics: Likelihood log. 502.175 - Cox R2 0.294 - Nagelkerke R2 0.438 - p<0.001

Source: MTMC 2015, N=8700, OFS, ARE

The banking and insurance sector was characterised in 2015 by a higher propensity for partial telework than in public administration, which was not the case in 2010. Partial telework has particularly increased between 2010 and 2015 in this sector. Telework is also more developed in sectors such as trade and mechanical repair, accommodation and catering, health, medico-social and social than in public administration. Table A1.5, in the appendix, shows that partial telehomework increased in almost all sectors except public administration.

The comparison of teleworking practices in 2010 and 2015 also shows that the use of teleworking has hardly changed in 5 years for employees working according to fixed schedules at the beginning or the end of the day. Teleworking increased in all other cases. This shows how flexible working time is a strong facilitating factor for the development of teleworking. 
The last difference between 2010 and 2015 that we want to highlight concerns residential location. Living in rural municipalities or in isolated cities was not linked with a higher propensity to telework in 2010 but this was the case in 2015. This result is the first indication of a link between teleworking and longer home to work commuting distances, all other things being equal, but also that telework may promote urban sprawl.

\subsection{Teleworking and mobility practices}

The second part of the analysis addresses the link between teleworking and mobility practices. As mentioned in the methodology section, we aggregate partial and intensive teleworkers to create a sufficiently large sample. We first evaluate the differences between people who telecommute and those who never do so in terms of commuting distance (figure 2). Teleworkers live further from their place of work than people who never telework: $20 \mathrm{~km}$ versus $15.7 \mathrm{~km}$ in 2010 and $24.6 \mathrm{~km}$ versus $16.1 \mathrm{~km}$ in 2015 . The difference in commuting distances between teleworkers and non-teleworkers has also increased as it amounted to $4.3 \mathrm{~km}$ in 2010 and $8.5 \mathrm{~km}$ in 2015 . In other words, while the commuting distance increased by $2.5 \%$ over a five-year period for non-telecommuters, it grew by $23 \%$ for teleworkers.

Figure 2: Commuting distances according to use of telework in 2010 and 2015

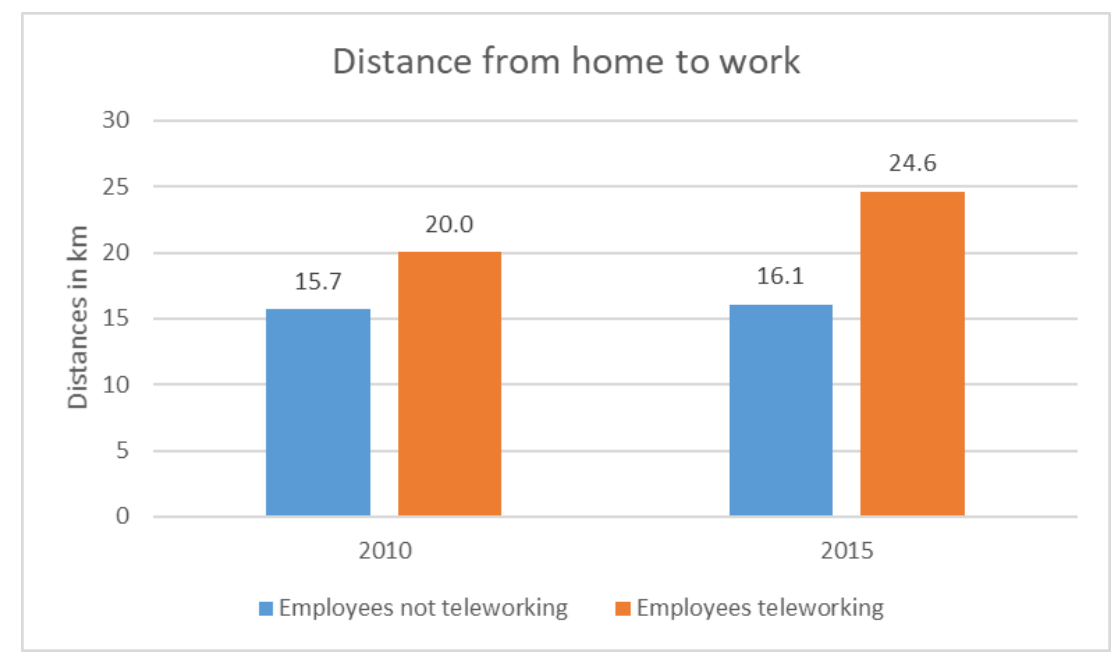

Significance for 2010: $\mathrm{F}=21.48$ and $\mathrm{p}<0.001$ - significance for $2015: \mathrm{F}=42.35$ and $\mathrm{p}<0.001$

Sources: MTMC 2010, N=2611 and 2015, N=2042, OFS, ARE

These differences in commuting distances may not only be related to telecommuting but also to socio-demographic profile, working conditions, and residential location. We assessed these potential effects using a linear regression, in which we used binary variables (table 3). Standardised Beta indicates the correlation coefficient between the explanatory variable (in the left-hand column) and commuting distances. S.E. is the Standard Error. The $t$ coefficient is the coefficient of the hypothesis test, and the stars to the right indicate the significance of the relationship.

As shown in table 3, many sociodemographic, professional or spatial variables play a role in home-work distance; it is higher for men than for women, for the highest education levels, for people who have flexible working hours, or who have no connection with the ownership of the company that employs them. It is therefore interesting to note that working in a self-owned or a family-member's business facilitates teleworking (tables 1 and 2) even if 
the home-work distances are lower for the workers considered. We would suggest that, in these cases, it relates to overtime. The crucial observation concerning our research question is that, all things being equal, teleworking plays a significant part in the distance between home and the work. The relationship is even more clearly significant in 2015 ( $<<0.001)$ than in $2010(p<0.05)$. Thus, teleworking for some days during the week is significantly linked with greater distances between home and work.

Table 3: Linear regression on commuting distances in 2010 and in 2015

\begin{tabular}{|c|c|c|c|c|c|c|c|}
\hline & & \multicolumn{3}{|c|}{ Commuting distances in 2010} & \multicolumn{3}{|c|}{ Commuting distances in 2015} \\
\hline & & stand. Beta & S.E. & $\mathrm{t}$ & stand. Beta & S.E. & $\mathrm{t}$ \\
\hline Age & Less than 30 y.o. & 0.052 & 0.968 & $2.442^{* *}$ & 0.015 & 0.568 & 1.657 \\
\hline Gender & Male & 0.013 & 0.966 & 0.618 & 0.042 & 0.526 & $4.559 * * *$ \\
\hline \multirow{2}{*}{$\begin{array}{l}\text { Educational } \\
\text { level }\end{array}$} & Secondary school & 0.062 & 1.409 & 1.783 & 0.046 & 0.821 & $2.802^{* * *}$ \\
\hline & High school & 0.144 & 1.565 & $3.815^{* * *}$ & 0.078 & 0.875 & $4.464^{* * *}$ \\
\hline \multirow{3}{*}{$\begin{array}{l}\text { Household } \\
\text { type }\end{array}$} & Alone & -0.084 & 1.241 & $-3.730 * * *$ & 0.007 & 0.674 & 0.741 \\
\hline & Couple with child(-ren) & -0.057 & 0.952 & $-2.440 * *$ & -0.011 & 0.509 & -1.120 \\
\hline & Single parent family & -0.031 & 2.026 & -1.484 & -0.003 & 1.059 & -0.276 \\
\hline \multirow{2}{*}{$\begin{array}{l}\text { Household } \\
\text { Income }\end{array}$} & Low incomes & 0.001 & 1.635 & 0.047 & -0.004 & 1.212 & -0.451 \\
\hline & High incomes & 0.025 & 0.951 & 1.120 & 0.002 & 0.485 & 0.184 \\
\hline \multirow{2}{*}{$\begin{array}{l}\text { Flexibility in } \\
\text { working time }\end{array}$} & $\begin{array}{l}\text { Fixed hours at the beginning } \\
\text { and / or end of the day }\end{array}$ & -0.134 & 1.259 & $-4.362 * * *$ & -0.046 & 0.658 & $-3.556 * * *$ \\
\hline & $\begin{array}{l}\text { Set work periods or number } \\
\text { of hours }\end{array}$ & -0.075 & 1.193 & $-2.556^{* *}$ & -0.024 & 0.621 & $-1.959 *$ \\
\hline $\begin{array}{l}\text { Hierarchical } \\
\text { responsabilities }\end{array}$ & $\begin{array}{l}\text { With line management } \\
\text { responsibility }\end{array}$ & -0.001 & 0.926 & -0.053 & 0.004 & 0.501 & 0.352 \\
\hline $\begin{array}{l}\text { Company } \\
\text { ownership }\end{array}$ & $\begin{array}{l}\text { Employee in a self-owned or } \\
\text { family member's business }\end{array}$ & -0.077 & 2.052 & $-3.606 * * *$ & -0.024 & 0.887 & $-2.558 * *$ \\
\hline \multirow{9}{*}{$\begin{array}{l}\text { Business } \\
\text { sectors }\end{array}$} & Trade, mechanical repair & -0.003 & 4.306 & -0.166 & 0.026 & 2.498 & $3.002 * * *$ \\
\hline & Transport, storage, post & -0.008 & 6.058 & -0.405 & 0.014 & 2.902 & 1.630 \\
\hline & Accommodation and catering & -0.008 & 9.073 & -0.391 & -0.002 & 3.139 & -0.216 \\
\hline & $\begin{array}{l}\text { Information and } \\
\text { communication }\end{array}$ & 0.008 & 6.025 & 0.414 & 0.016 & 2.549 & 1.843 \\
\hline & Banks, insurance & -0.013 & 3.814 & -0.657 & 0.019 & 2.867 & $2.171^{*}$ \\
\hline & Education & -0.020 & 6.451 & -0.975 & 0.011 & 2.313 & 1.264 \\
\hline & Health, social, medico-social & -0.031 & 4.086 & -1.505 & 0.008 & 2.094 & 0.909 \\
\hline & Other, property repairs & -0.019 & 4.148 & -0.929 & 0.008 & 2.659 & 0.922 \\
\hline & Domestic services & -0.014 & 16.058 & -0.680 & -0.005 & 3.719 & -0.611 \\
\hline \multirow{3}{*}{$\begin{array}{l}\text { Residential } \\
\text { location }\end{array}$} & Suburban municipalities & 0.010 & 0.962 & 0.436 & 0.027 & 0.511 & $2.661 * * *$ \\
\hline & Isolated cities & 0.035 & 4.957 & 1.733 & -0.004 & 2.578 & -0.438 \\
\hline & Rural municipalities & 0.073 & 1.128 & $3.061^{* * *}$ & 0.063 & 0.624 & $6.114 * * *$ \\
\hline \multirow[t]{2}{*}{ Telework } & Employee teleworking & 0.044 & 1.139 & $1.978^{*}$ & 0.042 & 0.560 & $4.170 * * *$ \\
\hline & Constant & & 2.060 & $6.113 * * *$ & & 1.110 & $6.221 * * *$ \\
\hline
\end{tabular}

$\mathrm{p}<0.05-* * \mathrm{p}<0.01-* * * \mathrm{p}<0.00$

2010 Model characteristics: $F=486.947$ - adjusted R2 $0.035-\mathrm{p}<0.001$

2015 Model characteristics: $F=8.013$ - adjusted R2 $0.014-\mathrm{p}<0.001$

Source: MTMC 2010, N=2611, MTMC 2015, N=2042, OFS, ARE 
In addition to the distance between places of residence and work, we characterised all journeys made during a day spent at the workplace for any purpose (leisure, shopping, giving people lifts, etc.). To make it possible to specify working days at home and teleworking days, we only consider full-time employees who were surveyed on a week day in the following analyses. A working day in the workplace is considered as such when the employee spent at least 5 hours in the workplace. A teleworking day is a week day with at least 5 hours spent at home between 9am to $5 \mathrm{pm}$. Teleworkers travel more on days when they commute than their counterparts who never telework (figure 3). The extra distance is mainly travelled using public transport, especially by train. This difference in the modes of transportation is almost entirely due to commuting. More generally, in Switzerland, the modal share of train travel is increasing sharply in line with the length of commuting trips (OFS, 2018), which may be explained by the ability of people to use their travel time for other purposes.

Figure 3: Distances by mode of transport on working days in the workplace according to the use of telework

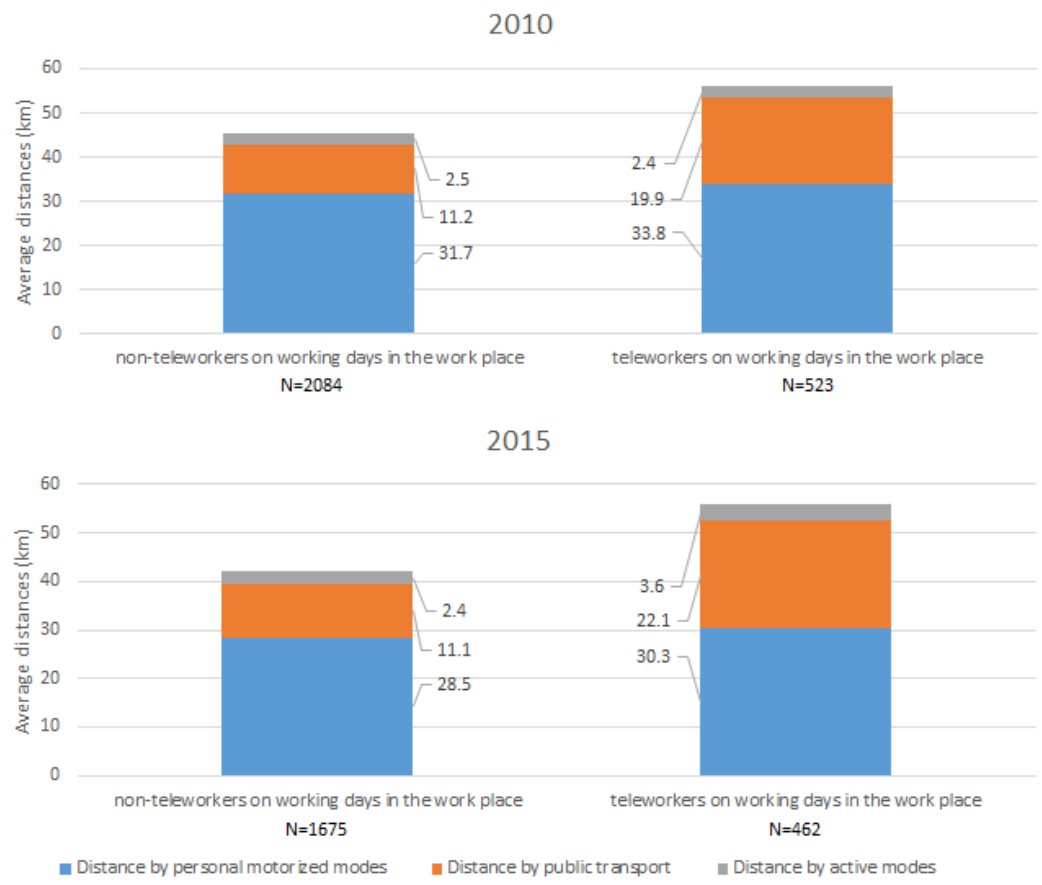

Source: MTMC 2010 and 2015, OFS, ARE

If we now consider solely teleworkers, we can assess the distances travelled on days when they work either at home or in the office. There are strong differences in the distances travelled depending on whether the person works at home or in the workplace. In 2010, teleworkers travelled 56.1 kilometres on the days on which they went to their workplace and 23.8 kilometres on the days they stayed at home and teleworked. In 2015, these distances amount respectively to 56 kilometres and 18.4 kilometres. On the whole the distance travelled was $67 \%$ lower in 2015 on non-telecommuting days. Journeys on telework days are less likely to be made by public transport and relate more to taking children to school, or other activities such as shopping or leisure. These activities would certainly not have been possible if the employee had to commute or would have been carried out by somebody else. 
Figure 4: Distances by mode of transport on working days depending on working at home or at the workplace

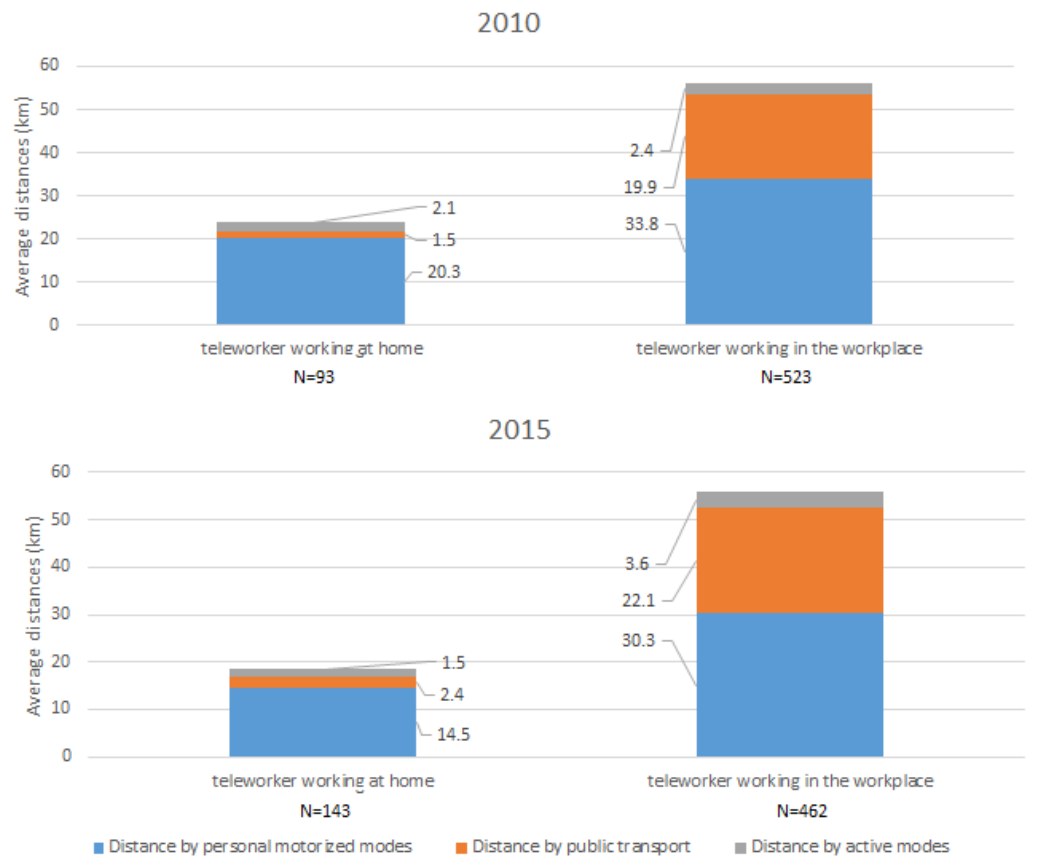

Source: MTMC 2010 and 2015, OFS, ARE

To complete our analysis, we estimated the average total distance travelled over a full working week for all purposes. For teleworkers, we took into account only full-time employees and we combined the average distances travelled on teleworking and commuting days with the average share of working time that is teleworked. For those who do not telework, we took into account only full-time employees and multiplied the distances that they travel on a working day by five.

In 2010, people who did not telework travelled an estimated average of 227 kilometres over the five working days $(\mathrm{N}=2084)$. Those who teleworked travelled $242.7 \mathrm{~km}$ during the same time $(\mathrm{N}=616)$. The gap grew in 2015 as the distances amounted respectively to 210 to 244.4 kilometres ( $\mathrm{N}=1675$ and $\mathrm{N}=605$ respectively). This gap may not be very marked but it confirms that teleworking does not globally reduce travel distances. In terms of ecological footprint, teleworkers use more public transport but this seems to be due to the extra commuting time that can be spent working, resting, etc. 
Figure 5: Mean distances travelled per week by full-time employees

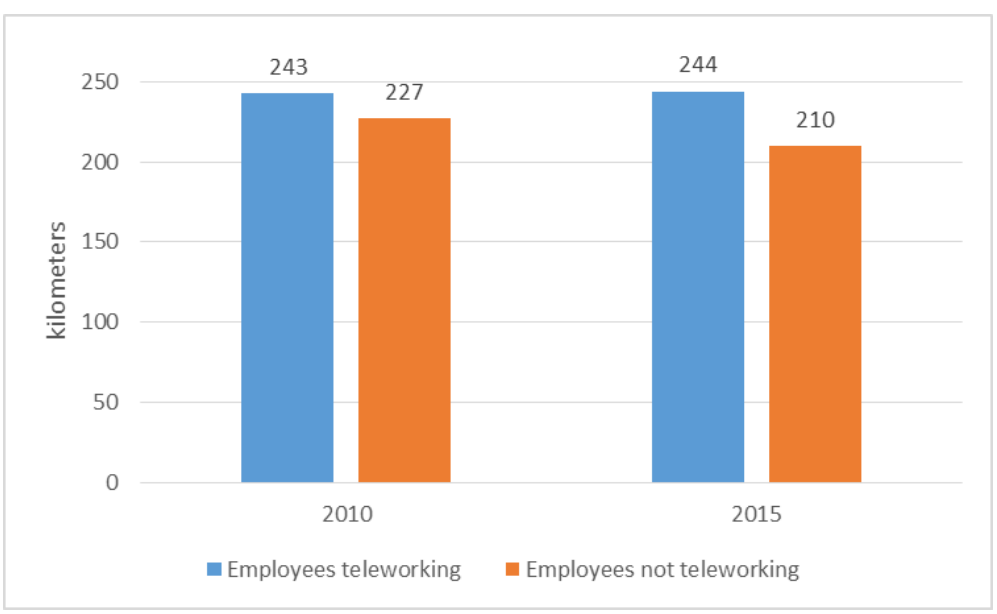

Source: MTMC 2010 and 2015, OFS, ARE

This kind of calculation might be weakened by the methodological approach. To better assess the existence of a potential rebound effect over a week, it would be beneficial to use data collected over a complete week for each person. Such data would also make it possible to specify whether the difference in distances travelled during the week between teleworkers and non-teleworkers is explained by the use of telework or by sociodemographic and socioeconomic differences. With the data source we use here, however, it is not possible to perform such an analysis.

\section{Conclusion and discussion}

Teleworking is an increasing practice that can take many forms. While there is wide agreement within political discourse on the role that teleworking could play to regulate mobility in cities, some scholars have argued that a rebound effect may be observed (Rietveld, 2011; Lachapelle et al., 2017). In order to explore these issues we have analysed the case of Switzerland using data from 2010 and 2015.

Our paper demonstrates, firstly, that the proportion of teleworkers is increasing in Switzerland. Employees who telework partially (less than $30 \%$ of their working time) account for $18 \%$ and the proportion of people who spend even more time working at home is just above $6 \%$. Looking at the profile of teleworkers, our results confirm the observations made by Vilhelmson and Thulin (2016) in Sweden, who highlight that having flexible working hours and working in certain sectors of activity, including information and communication, education or the scientific field, largely favor teleworking practices. Consistent with the literature (e Silva and Melo, 2018), we also demonstrated a greater use of teleworking among people with the highest salaries and level of education.

In terms of the effect of telework on mobility practices, a primary result is that teleworkers on average live further away from their workplace $(24.6 \mathrm{~km})$ than non-teleworkers $(16.1 \mathrm{~km})$ and this difference is increasing over time. The difference is still significant when variables related to profile, working conditions and residential location are controlled. Being able to telework for part of the week may increase tolerance of long-distance commuting. Telework and long-distance commuting seem to go hand in hand. Secondly, non-work-related journeys made on teleworking days partially offset the avoided commute. Overall, distance travelled is $67 \%$ lower on nontelecommuting days. These results are in line with the literature review by Walls and Safirova (2004). Compared 
over a working week, telecommuters travel longer distances (estimated at $244 \mathrm{~km}$ ) in comparison to nonteleworkers $(210 \mathrm{~km})$. A rebound effect may be observed in terms of distance travelled although it might not be the case in terms of energy consumption as telecommuters rely more on public transportation than the average.

Our paper is based on a secondary analysis of the Mobility and Transport Microcensus. This approach has the advantage of being based on a large-scale survey but it does not enable us to analyse the mechanisms and factors behind the practice of teleworking in detail. If teleworkers live further from their workplace than those who do not (whether by choice or otherwise), the causal link between these two parameters is difficult to assess and requires more research (e.g. through ad-hoc surveys and interviews). Residential location choices involve complex tradeoffs that involve all members of a household. The multiplicity of criteria at stake means that residential location is never optimised on the sole basis of its proximity to the workplace, especially in the case of dual-career couples (Deding et al., 2009). There is also an inherent inertia in residential mobility, especially since various moorings are built around the dwelling (Rérat, 2014; Vincent-Geslin and Kaufmann, 2012; Rérat and Lees, 2011). These choices and their temporality are therefore of great importance. The workplace is also decisive in the spatialisation of people's activities and mobility. However, the choice of a job is only weakly influenced by its location (Bunel, 2009). These elements call for residential location and career approaches a biographical or life course approach in order to identify the life events and mobility milestones that trigger teleworking practices (Rau and Manton, 2016). This would make it possible to better assess the role of teleworking on the tolerance of employees with regard to distance from work or what could be considered as a support for residential inertia.

An additional limitation of the source that we used in respect of assessing the impact of teleworking on spatial mobilities, is its restriction to the more classic form of teleworking (work-related activities performed at home). As mentioned in the theoretical section, teleworking encompasses other forms such as teleworking in a third place and during travel (itinerant teleworking) (Thomsin, 2002). Researching itinerant telecommuting would help us to better understand the links between teleworking and commuting distance. Indeed, the majority of the longest commuter journeys are carried out by train (OFS, 2018, Ravalet et al., 2015). This is explained by the fact that workers are increasingly using commuting time to work (Frei et al., 2015; Lyons et al., 2016) and that the alternative use of travel time is facilitated on public transport (Keseru and Macharis, 2018) as opposed to trips made by car during which the traveller must concentrate on driving. Researching teleworking in third places is crucial in a context where co-working spaces are increasingly prevalent. It would be interesting to compare their impacts on spatial mobilities as compared with the more traditional form of teleworking at home.

On the whole, given the results presented in this paper, it is apparent that teleworking needs to be studied using a systemic approach that integrates both daily and residential mobilities. This is especially important given the suggested rebound effect in the case of Switzerland, and the fact that teleworking seems to reduce the number of journeys but not the distance travelled. As teleworking will continue to grow due to digitalisation, it is necessary to broaden our understanding of the effects of its various forms on spatial mobilities. 


\section{References}

Aguilera, A., Lethiais, V., Rallet, A. and Proulhac, L. (2016) Home-based telework in France: Characteristics, barriers and perspectives. Transportation Research Part A: Policy and Practice, 92, pp. 1-11.

Bunel, M. (2009) Concilier travail et vie familiale: que cachent les déclarations des hommes et des femmes ? in Paihle, A. and Solaz, A. (ed.) Entre famille et travail, Paris, La documentation Française, pp. 141-164.

Deloitte (2016) L'espace de travail du futur. Comment la technologie numérique et l'économie du partage sont en train de changer la population active suisse.

https://www2.deloitte.com/ch/fr/pages/consumer-business/articles/workplace-of-the-future.html\#

e Silva, J.D.A. and Melo, P.C. (2018) Home telework, travel behavior, and land-use patterns: A path analysis of British single-worker households. Journal of Transport and Land Use, 11, 1, pp. 419-441.

Ernst, M. (2007) La flexibilité du temps de travail: entre autonomie et contraintes. Une étude de cas en Suisse. Thèse de doctorat en Sociologie, Université de Marne-La-Vallée.

Frei, C., Mahmassani, H. S. and Frei, A. (2015) Making time count: Traveler activity engagement on urban transit. Transportation Research Part A: Policy and Practice, 76, pp. 58-70.

Helminen, V. and Ristimaki, M. (2007) Relationships between commuting distance, frequency and telework in Finland. Journal of Transport Geography, 15, pp. 331-342.

Hjorthol, R.J. (2006) Teleworking in some Norwegian urban areas - motives and transport effects. Urban Geography, 27, 7, pp. 610-627.

Hubert, J.-P. (2009) Dans les grandes agglomérations, la mobilité quotidienne des habitants diminue, et elle augmente ailleurs. Insee Première, 1252.

Janelle, D.G. (1986) Metropolitan expansion and the communications - transportation trade-off, in Hanson S. (dir.), The Geography of Urban Transportation, The Guilford Press, pp. 357-385.

Keseru, I. and Macharis, C. (2018) Travel-based multitasking: review of the empirical evidence. Transport Reviews, 38, 2, pp. 162-183.

Kim, S.N. (2017) Is telecommuting sustainable? An alternative approach to estimating the impact of home-based telecommuting on household travel. International Journal of Sustainable Transportation, 11, 2, pp. $72-85$.

Kim, S.N., Choo, S. and Mokhtarian, P.L. (2015) Home-based telecommuting and intra-household interactions in work and non-work travel: A seemingly unrelated censored regression approach, Transportation Research Part A: Policy and Practice, 80, pp. 197-214.

Lachapelle, U., Tanguay, G.A. and Neumark-Gaudet, L. (2017) Telecommuting and sustainable travel: Reduction of overall travel time, increases in non-motorised travel and congestion relief? Urban Studies, 55, no. 10.

Lyons, G., Jain, J., and Weir, I. (2016) Changing times - A decade of empirical insight into the experience of rail passengers in Great Britain. Journal of Transport Geography, 57, pp. 94-104.

Melo, P.C. and e Silva, J.D.A. (2017) Home telework and household commuting patterns in Great Britain. Transportation Research Part A: Policy and Practice, 103(C), pp. 1-24. 
Mokhtarian, P.L. (1991) Defining telecommuting, Transportation research record, 1305, pp. 273-281.

Mokhtarian, P.L., Collantes, G.O. and Gertz, C. (2004) Telecommuting, residential locations, and commute distance traveled: evidence from state of California employees, Environment and Planning A, 36, 10, pp. 1877 1897.

Maruyama, T. and Tietze, S. (2012) From anxiety to assurance: concerns and outcomes of telework. Personnel Review, 41, 4, pp. 450-469.

Nilles, J.M. (1991) Telecommuting and urban sprawl: Mitigator or inciter?, Transportation, 18, pp. 411-432.

OFS (Office Fédéral de la Statistique) (2018) Feuille d'information « La pendularité en Suisse 2016».

Ory, D.T. and Mokhtarian, P. (2006) Which came first, the telecommuting or the residential relocation? An empirical analysis of causality, Urban Geography, 27, 7, pp. 590-609.

Parent-Thirion, A., Fernandez Macias, E., Hurley, J. and Vermeylen, G. (2007) Fourth European working conditions survey, European foundation for the improvement of living and working conditions.

Perch-Nielsen, S., von Felten, N., Henzen, C., Meissner, J., Sprenger, M., Bieri, M., Arvantis, S., Seliger, F. and Ley, M. (2014) Auswirkungen neuer Arbeitsformen auf den Energieverbrauch und das Mobilitätsverhalten von Arbeitnehmenden, 290955, Bundesamt für Energie NFE, Bern.

Peters, P., Tijdens, K.G. and Wetzels, C. (2004) Employees' opportunities, preferences and practices in telecommuting adoption, Information and Management, 41, pp. 469-482.

Ravalet, E. and Rérat, P. (2017) Les Technologies de l'Information de la Communication (T.I.C.) peuvent-elles limiter nos déplacements? L’exemple du télétravail, in Bierlaire, M., Kaufmann, V. and Rérat, P. (dir.), La mobilité en questions, Série Enjeux mondiaux, Presses Polytechniques Universitaires Romandes.

Ravalet, E., Vincent-Geslin, S., Kaufmann, V. and Leveugle, J. (2015) Slices of (mobile) life. Loco and Forum Vies Mobiles.

Rérat, P. (2014) Highly qualified rural youth: Why do young graduates return to their home region? Children's Geographies, 12, 1, pp. 70-86.

Rérat, P. and Lees, L. (2011) Spatial capital, gentrification and mobility: evidence from Swiss core cities. Transactions of the Institute of British Geographers, 36, 1, pp. 126-142

Rietveld, P. (2011) Telework and the transition to lower energy use in transport: On the relevance of rebound effects. Environmental Innovation and Societal Transitions, 1, 1, pp. 146-151.

Rifkin, J. (2001) The age of access: The new culture of hypercapitalism. Penguin.

Rumley, P.A., Buser, M., Poschet, L. and Pulver, B. (1999) Télématique et nouvelles formes de travail, Etude pour le Conseil Suisse de la Science.

Singh, P., Paleti, R., Jenkins, S. and Bhat, C.R. (2013) On modeling telecommuting behavior: option, choice, and frequency, Transportation, 40, 2, pp. 373-396.

Song, Y. (2009) Unpaid work at home, Industrial relations, 48, 4, pp. 578-588. 
Sullivan, C. (2003) What's in a name? Definitions and conceptualisations of teleworking and homeworking, New Technology, Work and Employment, 18, 3, pp. 158-165.

Swiss Confederation (2016) Conséquences juridiques du télétravail, Rapport du Conseil fédéral en réponse au postulat 12.3166 Meier-Schatz, 16 novembre 2016.

https://www.bj.admin.ch/dam/data/bj/aktuell/news/2016/2016-11-16/ber-br-f.pdf

Taskin, L. and Schots, M. (2005) Flexibilité du temps de travail et relation d'emploi. Economies et Sociétés, Série Socio-Economie du Travail, Presses de l'ISMEA, 26, pp.1471-1501.

Taskin, L. and Vendramin, P. (2004) Le télétravail, une vague silencieuse: enjeux socio-économiques d'une nouvelle flexibilité, Louvain-La-Neuve, Presses Universitaires de Louvain.

Thomsin, L. (2002) Télétravail et mobilités, Editions des Universités de Liège.

Tremblay, D.-G., Paquet, R. and Najem, E. (2006) Telework: a way to balance work and family or an increase in work-family conflict? Canadian Journal of Communication, 31, 3, pp. 715-731.

Vilhelmson, B. and Thulin, E. (2016) Who and where are the flexible workers? Exploring the current diffusion of telework in Sweden. New technology, work and employment, 31, 1, pp. 77-96.

Vincent-Geslin, S. and Kaufmann, V. (dir.) (2012) Mobilité sans racines: Plus loin, plus vite... plus mobiles? Paris: Descartes \& Cie.

Walls, M.A. and Safirova, E.A. (2004) A Review of the Literature on Telecommuting and Its Implications for Vehicle Travel and Emissions, Discussion paper 04-44, Ressources for the future.

Walrave, M. and De Bee, M. (2005) teleworking@home or close to home, ESF-Agentschap Vlaanderen, Brussels. Zahavi, Y and Talvitie, A. (1980) Regularities in travel time and money expenditures, Transportation Research Record, 750, pp. 13-19.

Zhu, P. (2013) Telecommuting, household commute and location choice. Urban Studies, 50, pp. 2441-2459.

Zhu, P. and Mason, S.G. (2014) The impact of telecommuting on personal vehicle usage and environmental sustainability, International Journal of Environmental Science and Technology, 11, 8, pp. 2185-2200. 


\section{Appendix 1: Teleworking and employment status}

Table A1.1: Use of teleworking according to flexibility of working hours

\begin{tabular}{|c|c|c|c|c|}
\hline $\mathbf{2 0 1 0}$ & $\begin{array}{c}\text { Fixed hours at } \\
\text { the beginning } \\
\text { and / or end of } \\
\text { the day }\end{array}$ & $\begin{array}{c}\text { Set work periods } \\
\text { or number of } \\
\text { hours }\end{array}$ & $\begin{array}{c}\text { Totally flexible } \\
\text { schedules }\end{array}$ & All employees \\
\hline $\begin{array}{c}\text { No } \\
\text { telehomework }\end{array}$ & $87.7 \%$ & $79.6 \%$ & $60.5 \%$ & $78.9 \%$ \\
\hline $\begin{array}{c}\text { Partial } \\
\text { telehomework }\end{array}$ & $9.1 \%$ & $17.1 \%$ & $29.9 \%$ & $16.5 \%$ \\
\hline $\begin{array}{c}\text { Intensive } \\
\text { telehomework }\end{array}$ & $3.1 \%$ & $3.3 \%$ & $9.6 \%$ & $4.6 \%$ \\
\hline TOTAL & $100.0 \%$ & $100.0 \%$ & $100.0 \%$ & $100.0 \%$ \\
\hline
\end{tabular}

\begin{tabular}{|c|c|c|c|c|}
\hline 2015 & $\begin{array}{c}\text { Fixed hours at } \\
\text { the beginning } \\
\text { and / or end of } \\
\text { the day }\end{array}$ & $\begin{array}{c}\text { Set work periods } \\
\text { or number of } \\
\text { hours }\end{array}$ & $\begin{array}{c}\text { Totally flexible } \\
\text { schedules }\end{array}$ & All employees \\
\hline $\begin{array}{c}\text { No } \\
\text { telehomework }\end{array}$ & $87.9 \%$ & $73.9 \%$ & $53.7 \%$ & $75.7 \%$ \\
\hline $\begin{array}{c}\text { Partial } \\
\text { telehomework }\end{array}$ & $8.5 \%$ & $21.6 \%$ & $32.5 \%$ & $18.2 \%$ \\
\hline $\begin{array}{c}\text { Intensive } \\
\text { telehomework }\end{array}$ & $3.6 \%$ & $4.5 \%$ & $13.7 \%$ & $6.1 \%$ \\
\hline TOTAL & $100.0 \%$ & $100.0 \%$ & $100.0 \%$ & $100.0 \%$ \\
\hline
\end{tabular}

Source: MTMC 2010 and 2015, OFS, ARE

Table A1.2: Use of teleworking according to hours of work

\begin{tabular}{|c|c|c|c|c|}
\hline $\mathbf{2 0 1 0}$ & $\begin{array}{c}\text { Full-time } \\
\text { employee }\end{array}$ & $\begin{array}{c}\text { Part-time } \\
\text { employee }\end{array}$ & $\begin{array}{c}\text { Several part- } \\
\text { time jobs }\end{array}$ & All employees \\
\hline $\begin{array}{c}\text { No } \\
\text { telehomework }\end{array}$ & $79.4 \%$ & $78.4 \%$ & $66.7 \%$ & $78.9 \%$ \\
\hline $\begin{array}{c}\text { Partial } \\
\text { telehomework }\end{array}$ & $17.0 \%$ & $15.5 \%$ & $20.6 \%$ & $16.5 \%$ \\
\hline $\begin{array}{c}\text { Intensive } \\
\text { telehomework }\end{array}$ & $3.5 \%$ & $6.1 \%$ & $12.8 \%$ & $4.6 \%$ \\
\hline TOTAL & $100.0 \%$ & $100.0 \%$ & $100.0 \%$ & $100.0 \%$ \\
\hline
\end{tabular}

\begin{tabular}{|c|c|c|c|c|}
\hline 2015 & $\begin{array}{c}\text { Full-time } \\
\text { employee }\end{array}$ & $\begin{array}{c}\text { Part-time } \\
\text { employee }\end{array}$ & $\begin{array}{c}\text { Several part- } \\
\text { time jobs }\end{array}$ & All employees \\
\hline $\begin{array}{c}\text { No } \\
\text { telehomework }\end{array}$ & $76.4 \%$ & $75.5 \%$ & $62.3 \%$ & $75.7 \%$ \\
\hline $\begin{array}{c}\text { Partial } \\
\text { telehomework }\end{array}$ & $19.3 \%$ & $16.4 \%$ & $18.9 \%$ & $18.2 \%$ \\
\hline $\begin{array}{c}\text { Intensive } \\
\text { telehomework }\end{array}$ & $4.3 \%$ & $8.1 \%$ & $18.9 \%$ & $6.1 \%$ \\
\hline TOTAL & $100.0 \%$ & $100.0 \%$ & $100.0 \%$ & $100.0 \%$ \\
\hline
\end{tabular}

Source: MTMC 2010 and 2015, OFS, ARE

Table A1.3: Use of teleworking according to hierarchical responsibility 


\begin{tabular}{|c|c|c|c|}
\hline 2010 & $\begin{array}{c}\text { Employee with no } \\
\text { management } \\
\text { responsability }\end{array}$ & $\begin{array}{c}\text { Employee with line } \\
\text { management } \\
\text { responsibility }\end{array}$ & All employees \\
\hline $\begin{array}{c}\text { No } \\
\text { telehomework }\end{array}$ & $84.1 \%$ & $68.3 \%$ & $80.9 \%$ \\
\hline $\begin{array}{c}\text { Partial } \\
\text { telehomework }\end{array}$ & $12.1 \%$ & $25.4 \%$ & $15.4 \%$ \\
\hline $\begin{array}{c}\text { Intensive } \\
\text { telehomework }\end{array}$ & $3.8 \%$ & $6.3 \%$ & $3.6 \%$ \\
\hline TOTAL & $100.0 \%$ & $100.0 \%$ & $100.0 \%$ \\
\hline
\end{tabular}

\begin{tabular}{|c|c|c|c|}
\hline 2015 & $\begin{array}{c}\text { Employee with no } \\
\text { management } \\
\text { responsability }\end{array}$ & $\begin{array}{l}\text { Employee with line } \\
\text { management } \\
\text { responsibility }\end{array}$ & All employees \\
\hline $\begin{array}{c}\text { No } \\
\text { telehomework }\end{array}$ & $81.4 \%$ & $63.8 \%$ & $75.7 \%$ \\
\hline $\begin{array}{c}\text { Partial } \\
\text { telehomework }\end{array}$ & $13.2 \%$ & $28.5 \%$ & $18.2 \%$ \\
\hline $\begin{array}{c}\text { Intensive } \\
\text { telehomework }\end{array}$ & $5.3 \%$ & $7.7 \%$ & $6.1 \%$ \\
\hline TOTAL & $100.0 \%$ & $100.0 \%$ & $100.0 \%$ \\
\hline
\end{tabular}

Source: MTMC 2010 and 2015, OFS, ARE

Table A1.4: Use of teleworking according to links to ownership of the company

\begin{tabular}{|c|c|c|c|}
\hline $\mathbf{2 0 1 0}$ & $\begin{array}{c}\text { Employee in a self- } \\
\text { owned or family } \\
\text { member's business }\end{array}$ & $\begin{array}{c}\text { Employee in } \\
\text { another business }\end{array}$ & All employees \\
\hline $\begin{array}{c}\text { No } \\
\text { telehomework }\end{array}$ & $47.7 \%$ & $80.9 \%$ & $78.9 \%$ \\
\hline $\begin{array}{c}\text { Partial } \\
\text { telehomework }\end{array}$ & $32.5 \%$ & $15.5 \%$ & $16.5 \%$ \\
\hline $\begin{array}{c}\text { Intensive } \\
\text { telehomework }\end{array}$ & $19.8 \%$ & $3.6 \%$ & $4.6 \%$ \\
\hline TOTAL & $100.0 \%$ & $100.0 \%$ & $100.0 \%$ \\
\hline
\end{tabular}

\begin{tabular}{|c|c|c|c|}
\hline 2015 & $\begin{array}{c}\text { Employee in a self- } \\
\text { owned or family } \\
\text { member's business }\end{array}$ & $\begin{array}{c}\text { Employee in } \\
\text { another business }\end{array}$ & All employees \\
\hline $\begin{array}{c}\text { No } \\
\text { telehomework }\end{array}$ & $48.9 \%$ & $77.5 \%$ & $75.7 \%$ \\
\hline $\begin{array}{c}\text { Partial } \\
\text { telehomework }\end{array}$ & $28.6 \%$ & $17.5 \%$ & $18.2 \%$ \\
\hline $\begin{array}{c}\text { Intensive } \\
\text { telehomework }\end{array}$ & $22.5 \%$ & $5.0 \%$ & $6.1 \%$ \\
\hline TOTAL & $100.0 \%$ & $100.0 \%$ & $100.0 \%$ \\
\hline
\end{tabular}

Source: MTMC 2010 and 2015, OFS, ARE

Table A1.5: Use of teleworking according to sector of activity

\begin{tabular}{|c|c|c|c|c|c|c|c|c|c|c|}
\hline 2010 & $\begin{array}{l}\text { Trade, } \\
\text { mechanical } \\
\text { repair }\end{array}$ & $\begin{array}{l}\text { Transport, } \\
\text { storage, } \\
\text { post }\end{array}$ & $\begin{array}{c}\text { Accommodation } \\
\text { and catering }\end{array}$ & $\begin{array}{c}\text { Information } \\
\text { and } \\
\text { communication }\end{array}$ & $\begin{array}{c}\text { Banks, } \\
\text { insurance }\end{array}$ & $\begin{array}{c}\text { Public } \\
\text { administration }\end{array}$ & Education & $\begin{array}{l}\text { Health, social, } \\
\text { medico-social }\end{array}$ & $\begin{array}{c}\text { Other, } \\
\text { property } \\
\text { repair }\end{array}$ & $\begin{array}{l}\text { Domestic } \\
\text { services }\end{array}$ \\
\hline $\begin{array}{c}\text { No } \\
\text { telehomework }\end{array}$ & $85.1 \%$ & $91.8 \%$ & $93.9 \%$ & $57.1 \%$ & $71.9 \%$ & $84.0 \%$ & $38.8 \%$ & $77.6 \%$ & $83.9 \%$ & $76.8 \%$ \\
\hline
\end{tabular}




\begin{tabular}{|c|c|c|c|c|c|c|c|c|c|c|}
\hline $\begin{array}{c}\text { Partial } \\
\text { telehomework }\end{array}$ & $12.2 \%$ & $8.2 \%$ & $3.0 \%$ & $40.5 \%$ & $26.3 \%$ & $12.8 \%$ & $40.0 \%$ & $14.7 \%$ & $9.3 \%$ & $15.9 \%$ \\
\hline $\begin{array}{c}\text { Intensive } \\
\text { telehomework }\end{array}$ & $2.7 \%$ & $0.0 \%$ & $3.0 \%$ & $2.4 \%$ & $1.8 \%$ & $3.2 \%$ & $21.2 \%$ & $7.6 \%$ & $6.8 \%$ & $7.2 \%$ \\
\hline TOTAL & $100.0 \%$ & $100.0 \%$ & $100.0 \%$ & $100.0 \%$ & $100.0 \%$ & $100.0 \%$ & $100.0 \%$ & $100.0 \%$ & $100.0 \%$ & $100.0 \%$ \\
\hline
\end{tabular}

\begin{tabular}{|c|c|c|c|c|c|c|c|c|c|}
\hline 2015 & $\begin{array}{c}\text { Trade, } \\
\text { mechanical } \\
\text { repair }\end{array}$ & $\begin{array}{c}\text { Transport, } \\
\text { storage, } \\
\text { post }\end{array}$ & $\begin{array}{l}\text { Accommodation } \\
\text { and catering }\end{array}$ & $\begin{array}{l}\text { Information and } \\
\text { communication }\end{array}$ & $\begin{array}{c}\text { Banks, } \\
\text { insurance }\end{array}$ & $\begin{array}{c}\text { Public } \\
\text { administration }\end{array}$ & Education & $\begin{array}{l}\text { Health, social, } \\
\text { medico-social }\end{array}$ & $\begin{array}{l}\text { Other, } \\
\text { property } \\
\text { repair }\end{array}$ \\
\hline $\begin{array}{c}\text { No } \\
\text { telehomewo } \\
\text { rk }\end{array}$ & $77.2 \%$ & $88.6 \%$ & $84.1 \%$ & $42.1 \%$ & $60.0 \%$ & $88.6 \%$ & $43.1 \%$ & $79.5 \%$ & $66.3 \%$ \\
\hline $\begin{array}{c}\text { Partial } \\
\text { telehomewo } \\
\text { rk }\end{array}$ & $19.0 \%$ & $8.6 \%$ & $10.1 \%$ & $43.9 \%$ & $38.0 \%$ & $8.8 \%$ & $40.4 \%$ & $16.9 \%$ & $27.0 \%$ \\
\hline $\begin{array}{c}\text { Intensive } \\
\text { telehomewo } \\
\text { rk }\end{array}$ & $3.8 \%$ & $2.9 \%$ & $5.8 \%$ & $14.0 \%$ & $2.0 \%$ & $2.6 \%$ & $16.5 \%$ & $3.6 \%$ & $6.7 \%$ \\
\hline TOTAL & $100.0 \%$ & $100.0 \%$ & $100.0 \%$ & $100.0 \%$ & $100.0 \%$ & $100.0 \%$ & $100.0 \%$ & $100.0 \%$ & $100.0 \%$ \\
\hline
\end{tabular}

Source: MTMC 2010 and 2015, OFS, ARE

\section{Appendix 2: Teleworking and sociodemographic and economic profiles}

Table A2.1: Use of teleworking according to gender

\begin{tabular}{|c|c|c|}
\hline $\mathbf{2 0 1 0}$ & Male & Female \\
\hline $\begin{array}{c}\text { No } \\
\text { telehomework }\end{array}$ & $76.6 \%$ & $81.4 \%$ \\
\hline $\begin{array}{c}\text { Partial } \\
\text { telehomework }\end{array}$ & $19.3 \%$ & $13.3 \%$ \\
\hline $\begin{array}{c}\text { Intensive } \\
\text { telehomework }\end{array}$ & $4.1 \%$ & $5.3 \%$ \\
\hline TOTAL & $100.0 \%$ & $100.0 \%$ \\
\hline
\end{tabular}

\begin{tabular}{|c|c|c|}
\hline $\mathbf{2 0 1 5}$ & Male & Female \\
\hline $\begin{array}{c}\text { No } \\
\text { telehomework }\end{array}$ & $73.4 \%$ & $78.2 \%$ \\
\hline $\begin{array}{c}\text { Partial } \\
\text { telehomework }\end{array}$ & $21.2 \%$ & $14.8 \%$ \\
\hline $\begin{array}{c}\text { Intensive } \\
\text { telehomework }\end{array}$ & $5.4 \%$ & $6.9 \%$ \\
\hline TOTAL & $100.0 \%$ & $100.0 \%$ \\
\hline
\end{tabular}

Source: MTMC 2010 and 2015, OFS, ARE

Table A2.2: Use of teleworking according to age

\begin{tabular}{|c|c|c|}
\hline 2010 & $\begin{array}{c}\text { Less than } 30 \\
\text { y.o. }\end{array}$ & $\begin{array}{c}\text { More than } 30 \\
\text { y.o. }\end{array}$ \\
\hline $\begin{array}{c}\text { No } \\
\text { telehomework }\end{array}$ & $86.9 \%$ & $76.3 \%$ \\
\hline $\begin{array}{c}\text { Partial } \\
\text { telehomework }\end{array}$ & $10.4 \%$ & $18.5 \%$ \\
\hline $\begin{array}{c}\text { Intensive } \\
\text { telehomework }\end{array}$ & $2.8 \%$ & $5.2 \%$ \\
\hline TOTAL & $100.0 \%$ & $100.0 \%$ \\
\hline
\end{tabular}




\begin{tabular}{|c|c|c|}
\hline 2015 & $\begin{array}{c}\text { Less than } 30 \\
\text { y.o. }\end{array}$ & $\begin{array}{c}\text { More than } 30 \\
\text { y.o. }\end{array}$ \\
\hline $\begin{array}{c}\text { No } \\
\text { telehomework }\end{array}$ & $85.4 \%$ & $72.8 \%$ \\
\hline $\begin{array}{c}\text { Partial } \\
\text { telehomework }\end{array}$ & $11.5 \%$ & $20.2 \%$ \\
\hline $\begin{array}{c}\text { Intensive } \\
\text { telehomework }\end{array}$ & $3.1 \%$ & $7.0 \%$ \\
\hline TOTAL & $100.0 \%$ & $100.0 \%$ \\
\hline
\end{tabular}

Source: MTMC 2010 and 2015, OFS, ARE

Table A2.3: Use of teleworking according to level of education

\begin{tabular}{|c|c|c|c|}
\hline $\mathbf{2 0 1 0}$ & $\begin{array}{c}\text { Compulsory } \\
\text { school }\end{array}$ & $\begin{array}{c}\text { Secondary } \\
\text { school }\end{array}$ & Higher education \\
\hline $\begin{array}{c}\text { No } \\
\text { telehomework }\end{array}$ & $92.9 \%$ & $85.1 \%$ & $63.0 \%$ \\
\hline $\begin{array}{c}\text { Partial } \\
\text { telehomework }\end{array}$ & $4.2 \%$ & $11.2 \%$ & $30.1 \%$ \\
\hline $\begin{array}{c}\text { Intensive } \\
\text { telehomework }\end{array}$ & $2.9 \%$ & $3.6 \%$ & $7.0 \%$ \\
\hline TOTAL & $100.0 \%$ & $100.0 \%$ & $100.0 \%$ \\
\hline
\end{tabular}

\begin{tabular}{|c|c|c|c|}
\hline $\mathbf{2 0 1 5}$ & $\begin{array}{c}\text { Compulsory } \\
\text { school }\end{array}$ & $\begin{array}{c}\text { Secondary } \\
\text { school }\end{array}$ & Higher education \\
\hline $\begin{array}{c}\text { No } \\
\text { telehomework }\end{array}$ & $93.2 \%$ & $84.0 \%$ & $60.1 \%$ \\
\hline $\begin{array}{c}\text { Partial } \\
\text { telehomework }\end{array}$ & $4.0 \%$ & $11.3 \%$ & $31.0 \%$ \\
\hline $\begin{array}{c}\text { Intensive } \\
\text { telehomework }\end{array}$ & $2.8 \%$ & $4.7 \%$ & $8.9 \%$ \\
\hline TOTAL & $100.0 \%$ & $100.0 \%$ & $100.0 \%$ \\
\hline
\end{tabular}

Source: MTMC 2010 and 2015, OFS, ARE

Table A2.4: Use of teleworking according to type of household

\begin{tabular}{|c|r|r|r|r|r|}
\hline 2010 & Alone & \multicolumn{1}{c|}{$\begin{array}{c}\text { Couple } \\
\text { without } \\
\text { children }\end{array}$} & $\begin{array}{c}\text { Couple with } \\
\text { children }\end{array}$ & $\begin{array}{c}\text { Single parent } \\
\text { family }\end{array}$ & Other \\
\hline $\begin{array}{c}\text { No } \\
\text { telehomework }\end{array}$ & $82.2 \%$ & $77.7 \%$ & $78.0 \%$ & $83.5 \%$ & $78.0 \%$ \\
\hline $\begin{array}{c}\text { Partial } \\
\text { telehomework }\end{array}$ & $13.7 \%$ & $17.6 \%$ & $17.2 \%$ & $12.6 \%$ & $17.1 \%$ \\
\hline $\begin{array}{c}\text { Intensive } \\
\text { telehomework }\end{array}$ & $4.1 \%$ & $4.7 \%$ & $4.8 \%$ & $3.9 \%$ & $4.9 \%$ \\
\hline TOTAL & $100.0 \%$ & $100.0 \%$ & $100.0 \%$ & $100.0 \%$ & $100.0 \%$ \\
\hline
\end{tabular}

\begin{tabular}{|c|r|r|r|r|r|}
\hline 2015 & Alone & $\begin{array}{c}\text { Couple } \\
\text { without } \\
\text { children }\end{array}$ & $\begin{array}{c}\text { Couple with } \\
\text { children }\end{array}$ & $\begin{array}{c}\text { Single parent } \\
\text { family }\end{array}$ & Other \\
\hline $\begin{array}{c}\text { No } \\
\text { telehomework }\end{array}$ & $77.5 \%$ & $74.8 \%$ & $74.5 \%$ & $81.6 \%$ & $76.0 \%$ \\
\hline $\begin{array}{c}\text { Partial } \\
\text { telehomework }\end{array}$ & $17.3 \%$ & $18.5 \%$ & $19.3 \%$ & $13.8 \%$ & $17.7 \%$ \\
\hline $\begin{array}{c}\text { Intensive } \\
\text { telehomework }\end{array}$ & $5.2 \%$ & $6.8 \%$ & $6.3 \%$ & $4.6 \%$ & $6.3 \%$ \\
\hline
\end{tabular}




\begin{tabular}{|c|r|r|r|r|r|}
\hline TOTAL & $100.0 \%$ & $100.0 \%$ & $100.0 \%$ & $100.0 \%$ & $100.0 \%$ \\
\hline
\end{tabular}

Source: MTMC 2010 and 2015, OFS, ARE

Table A2.5: Use of teleworking according to income

\begin{tabular}{|c|c|c|c|}
\hline $\mathbf{2 0 1 0}$ & Low incomes & $\begin{array}{c}\text { Medium } \\
\text { Incomes }\end{array}$ & High Incomes \\
\hline $\begin{array}{c}\text { No } \\
\text { telehomework }\end{array}$ & $88.1 \%$ & $82.2 \%$ & $67.3 \%$ \\
\hline $\begin{array}{c}\text { Partial } \\
\text { telehomework }\end{array}$ & $7.3 \%$ & $13.8 \%$ & $27.0 \%$ \\
\hline $\begin{array}{c}\text { Intensive } \\
\text { telehomework }\end{array}$ & $4.6 \%$ & $4.0 \%$ & $5.7 \%$ \\
\hline TOTAL & $100.0 \%$ & $100.0 \%$ & $100.0 \%$ \\
\hline
\end{tabular}

\begin{tabular}{|c|c|c|c|}
\hline $\mathbf{2 0 1 5}$ & Low incomes & $\begin{array}{c}\text { Medium } \\
\text { Incomes }\end{array}$ & High Incomes \\
\hline $\begin{array}{c}\text { No } \\
\text { telehomework }\end{array}$ & $84.6 \%$ & $82.5 \%$ & $63.2 \%$ \\
\hline $\begin{array}{c}\text { Partial } \\
\text { telehomework }\end{array}$ & $10.2 \%$ & $12.7 \%$ & $29.1 \%$ \\
\hline $\begin{array}{c}\text { Intensive } \\
\text { telehomework }\end{array}$ & $5.2 \%$ & $4.9 \%$ & $7.7 \%$ \\
\hline TOTAL & $100.0 \%$ & $100.0 \%$ & $100.0 \%$ \\
\hline
\end{tabular}

Source: MTMC 2010 and 2015, OFS, ARE 